

\section{australian ARCHAEOLOGY}

Australian Archaeology, the official publication of the Australian Archaeological Association Inc., is a refereed journal published since 1974. It accepts original articles in all fields of archaeology and other subjects relevant to archaeological research and practice in Australia and nearby areas. Contributions are accepted in eight sections: Articles (5000-8000 words), Short Reports (1000-3000), Obituaries (500-2000), Thesis Abstracts (200-500), Book Reviews (500-2000), Forum (5000), Comment (1000) and Backfill (which includes letters, conference details, announcements and other material of interest to members). Australian Archaeology is published twice a year, in June and December. Notes to Contributors are available at: $<$ www.australianarchaeologicalassociation.com.au>

Australian Archaeology is indexed in the Arts and Humanities Citation Index of the ISI Web of Knowledge, SCOPUS, Australian Public Affairs Information Service (APAIS) and Anthropological Literature and Anthropological Index Online.

Australian Archaology is ranked as a tier A journal by the European Reference Index for the Humanities and French Agence d'Evaluation de la Recherche et de l'Enseignement Supérieur.

Subscriptions are available to individuals through membership of the Australian Archaeological Association Inc. or to organisations through institutional subscription. Subscription application/renewal forms are available at $<$ www.australianarchaeologicalassociation.com.au $>$ Australian Archaeology is available through Informit and JSTOR.

Graphic Design: Lovehate Design
Printing:

Front Cover: The Willandra Fossil Trackway, southwestern New South Wales. Children from the three traditional tribal groups of the Willandra Lakes walk on the site of what promises to be the world's largest collection of Pleistocene human footprints in the world (photograph courtesy of Michael Amendolia).

All correspondence and submissions should be addressed to: Australian Archaeology

PO Box 10, Flinders University LPO

Flinders University SA 5048

Email:journal@australianarchaeology.com

URL: <http://www.australianarchaeologicalassociation.com.au>

The views expressed in this journal are not necessarily those of the Australian Archaeological Association Inc. or the Editors.
Editors

Heather Burke Flinders University

Lynley Wallis Wallis Heritage Consulting

\section{Editorial Advisory Board}

Val Attenbrow Australian Museum Huw Barton Leicester University Bruno David Monash University Judith Field University of New South Wales Joe Flatman University College London Richard Fullagar Scarp Archaeology Susan Lawrence La Trobe University Judith Littleton University of Auckland Scott L'Oste-Brown Central Queensland Cultural Heritage Management Jo McDonald The University of Western Australia Patrick Moss The University of Queensland Tim Murray La Trobe University Jim O'Connell University of Utah Sven Ouzman The University of Western Australia Fiona Petchey University of Waikato Alistair Pike Bristol University Annie Ross The University of Queensland Nancy Tayles University of Otago Robin Torrence Australian Museum Sean Ulm James Cook University Peter Veth The University of Western Australia David Whitley ASM Affiliates Inc.

Michael Williams The University of Queensland

\section{Short Report Editor}

Sean Winter The University of Western Australia

Book Review Editors

Alice Gorman Flinders University

Jane Lydon The University of Western Australia

Thesis Abstract Editor

Tiina Manne The University of Queensland

\section{Editorial Assistant}

Susan Arthure Flinders University

\section{Commissioned Bloggers}

Jacqueline Matthews The University of Queensland Michelle Langley University of Oxford 



\title{
Birriwilk rockshelter: A mid- to late Holocene site in Manilikarr Country, southwest Arnhem Land, Northern Territory
}

\author{
Denis Shine ${ }^{1}$, Duncan Wright ${ }^{2}$, Tim Denham ${ }^{3}$, Ken Aplin ${ }^{4}$, Peter Hiscock ${ }^{5}$, Kim Parker ${ }^{1}$ and \\ Ronni Walton ${ }^{6}$
}

\begin{abstract}
Recent excavations at the Birriwilk rockshelter in Mikinj Valley, southwest Arnhem Land, have revealed evidence for mid- to late Holocene settlement, including a major period of site use in the last millennium. The site is important to the traditional owners, with a rich oral tradition associated with 'Birriwilk', an ancestor of the Urningangk tribe, who is depicted in rock art at the site. Oral traditions link Birriwilk with an adjacent lagoon, as well as a number of other rock art sites and features in the landscape, including the renowned Ubirr complex. The Birriwilk site and vicinity are significant places to the Nayinggul family, traditional owners for the Manilikarr estate. This post-fieldwork report summarises key archaeological findings at Birriwilk, using frequencies of stone artefacts and faunal remains as proxies of occupation from ca 5000 years ago. The most intense occupation occurred within the last 700 years, a period characterised by foraging and hunting in adjacent wetland habitats, changing technological emphasis to the manufacture of bifacial quartzite points, increased artefact discard rates and increased ochre grinding. The site has little archaeological evidence of use during the last 200 years, although oral histories indicate it was visited regularly until the mid-twentieth century. The rockshelter remains an important story site today.
\end{abstract}

\section{Introduction}

During September and October 2011, archaeological excavations were undertaken at Birriwilk, a rockshelter in Manilikarr country, East Alligator Region of southwest Arnhem Land, Northern Territory (Figure 1). The excavations are part of a community-led doctoral research program by the lead author. Sites were selected in consultation with the Nayinggul family, who wished to better understand the settlement history of Birriwilk, as they regard the rockshelter to be one of the most significant sites within their Country. This short report summarises excavation results,

\footnotetext{
School of Geography and Environmental Science, Monash University Clayton, Melbourne Vic. 3800, Australia <denis.shine@monash.edu> <kim.parker@monash.edu>

Place, Evolution and Rock Art Heritage Unit, School of Humanities, Gold Coast Campus, Griffith University Old 4222, Australia <d.wright@griffith.edu.au>

${ }^{3}$ School of Historical and European Sciences, Archaeology Program, La Trobe University, Melbourne Vic. 3086, Australia $<$ t.denham@latrobe.edu.au>

${ }^{4}$ Department of Archaeology and Natural History, College of Asia and the Pacific, The Australian National University, Canberra ACT 0200, Australia <aplin.ken@gmail.com>

${ }^{5}$ Department of Archaeology, School of Philosophical and Historical Inquiry, Faculty of Arts and Social Sciences, University of Sydney, Sydney NSW 2006, Australia <peter.hiscock@sydney.edu.au>

${ }^{6}$ School of Social Science, University of Queensland, St Lucia Old 4072, Australia <ronni.walton@uqconnect.edu.au>
}

interpreting settlement history through dated distributions of faunal remains and stone artefacts, augmented by analyses of burning patterns and distributions of worked ochre. The significance of the site's occupational sequence, rock art and oral histories for interpreting the spatio-temporal aspects of the Birriwilk story will be assessed in a future publication.

\section{Manilikarr Country}

Manilikarr Country is a clan territory that encompasses both sides of the East Alligator River and lies south of Kunbarlanja (Oenpelli). It primarily lies within west Arnhem Land (declared an Aboriginal Reserve in 1931), although it extends into present day Kakadu National Park (KNP). The clan area was, until late 2011, named after the recently deceased senior traditional owner, who is referred to herein by his skin name Nakodjok. Nakodjok supported the archaeological investigations at Birriwilk (as well as at two other rockshelters, Ingaanjalwurr and Bindjarran), and several members of his family participated in the excavations. The language of Manilikarr Country was traditionally Urningangk, which was restricted to an area directly south of Kunbarlanja centred on Mikinj Valley (Birch 2006). Nakodjok is reputed to have been the last 'hearer' of this language, which has been displaced by Kunwinggu.

Until this research, excavations had not been conducted in Manilikarr country since the 1960s (Schrire 1982; White 1967a, 1967b, 1971; White and Peterson 1969), although several other rockshelters have been excavated more recently in close proximity to the estate (e.g. Allen and Barton 1989; Jones 1985; Kamminga and Allen 1973). A number of rock art surveys have also been undertaken in Manilikarr country (e.g. Brandl 1968; Edwards 1979; Gunn 1992; Jelínek 1976, 1978, 1979; Mountford 1956; Taçon 1989) and ethnographic information has been documented for the estate (e.g. Berndt 1962; Chaloupka et al. 1985; Mountford 1956). In 1991, Gunn (1992) obtained oral histories and produced a partial record of the rock art at Birriwilk. The significance of the site lies in its importance to traditional owners and its association with the Rainbow Serpent, as well as potentially with creation stories for the East Alligator River.

\section{Oral Traditions}

During visits to Birriwilk in 2011, oral histories from three generations of the Nayingguls (Nakodjok, Alfred Nayinggul and Andronicus Nayinggul) were documented (by DS). As has been noted elsewhere, their accounts were generationally differentiated (Merlan 1998); however, the core of the story was the same. Several previous detailed accounts of Birriwilk and the 


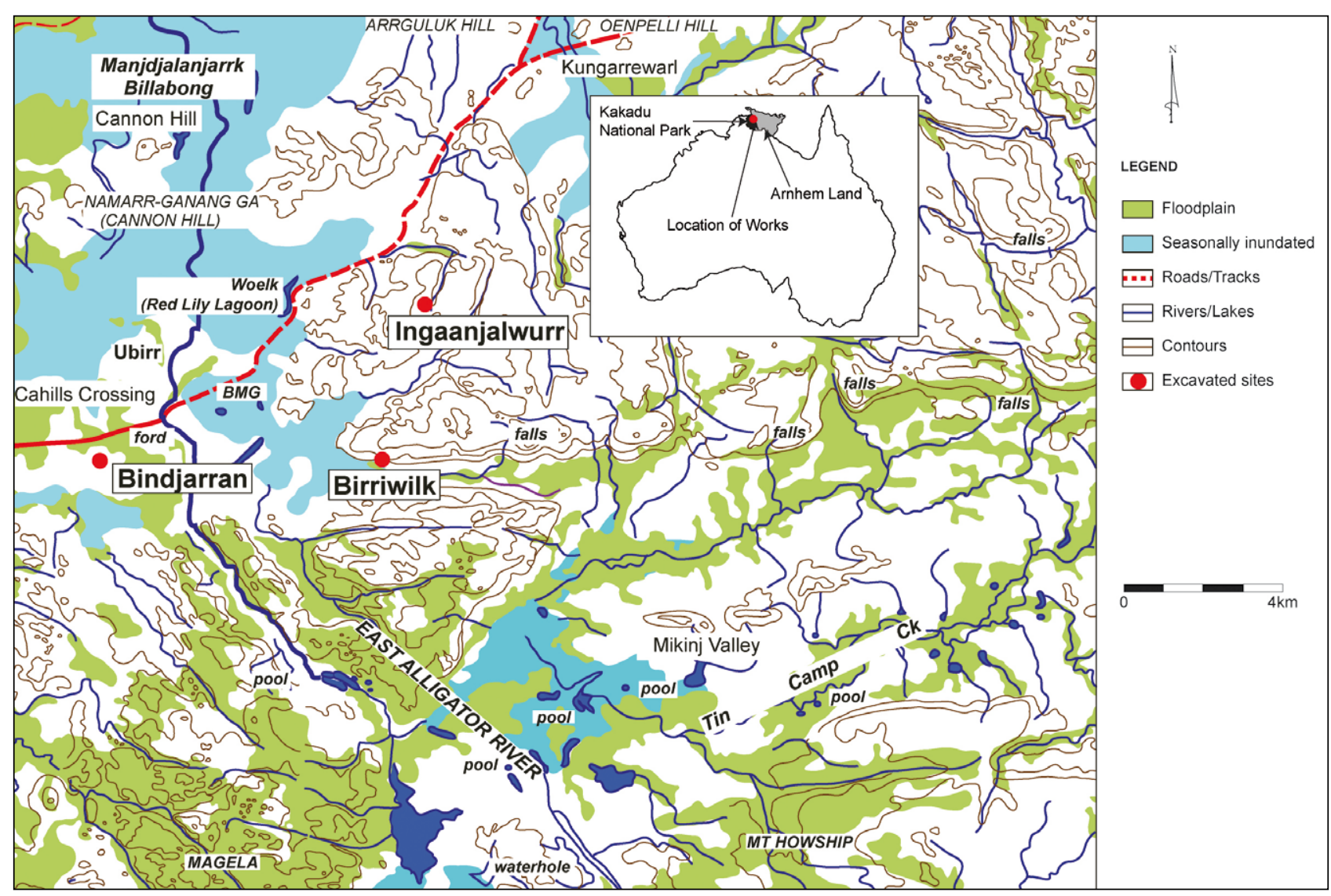

Figure 1 Location of Birriwilk and other excavated archaeological rockshelters (Map Grid of Australia Zone 53; Geocentric Datum of Australia 94).

rockshelter have also been recorded (e.g. Aboriginal Arts Board 1979; Berndt and Berndt 1989; Gunn 1992; also see Edwards 1979; Jelínek 1976; Taçon 1989).

Nakodjok held Birriwilk to be the most significant site within Mikinj, an area particularly pertinent to the Nayingguls. He remembered staying there 'many times' when Kunbarlanja was 'nothing', to hunt or collect geese eggs, yams and 'many types of food'. He identified one of the three hand stencils at the site as belonging to his father. The site is closely associated with the Rainbow Serpent, which, as elsewhere in Arnhem Land, is strongly associated with water (Merlan 1998; Taçon et al. 1996). David Canari (cited in Taçon 1989:234) credits Birriwilk with the creation of the East Alligator River, an account refuted by the Nayingguls. This review summarises stories relating to the rockshelter and the adjacent lagoon which were recounted during excavation.

Gunn (1992) recorded Birriwilk as 'coming from' the Rainbow Serpent, Ngalyod, at Ubirr. While not stated as such to us, Birriwilk was described as sacred and endowed with 'rainbowness'. Berndt and Berndt (1989:59) documented Birriwilk 'making herself' into a picture on the wall and having the power to send out children once touched. Both Gunn (1992) and Berndt and Berndt (1989) documented Birriwilk's travels across northern Australia, with camping sites at several locations, including rock bars on the East Alligator, before settling in Mikinj Valley. Here she met Njanjmah, the quoll or native cat, who became her husband. While collecting lilies in the lagoon, now also called Birriwilk, she was attacked by Ngalyod. After escaping, she painted herself-bloodied and disfigured from the attack-on the rockshelter wall, and
Njanjmah painted himself beside her (Figure 2). When attacked a second time in the lagoon Birriwilk could not escape and her husband Njanjmah built a raft to rescue her. This raft has been depicted for future generations at the site of Njanjmah, on the south side of the lagoon. On this occasion the whirlpool created by Ngalyod was too strong and the raft, Birriwilk and Njanjmah were consumed before being fossilised as rock at the bottom of the lagoon. This rock, a djang (sacred) site, is still exposed during extremely low water and can be felt underfoot. The lagoon is now considered safe to fish in, although swimming should still be avoided.

The story of Birriwilk is of critical importance for local people, linking three art locations-Ubirr, Birriwilk and Njanjmah (also referred to as Guluyambi or raft dreaming) as well as landscape features such as the lagoon and several rock bars (including Cahills Crossing). Other accounts afford Birriwilk even greater importance, associating her with the creation of the East Alligator River itself (Taçon 1989). The Birriwilk ancestral spirit remains significant to the Nayingguls and the community of Kunbarlanja today and recent accounts have documented her importance in the increase of fish supplies (Aboriginal Arts Board 1979:74). Birriwilk also remains in popular use as a girl's name.

\section{Birriwilk Rockshelter}

The Birriwilk rockshelter consists of an elevated terrace measuring approximately 13 by $7 \mathrm{~m}$, between a significant upward slope to the north-northeast and downward slope to the south-southwest. The site is partially enclosed by a cliff overhang on its eastern side, formed by block disintegration or undercutting of the cliff face. The 

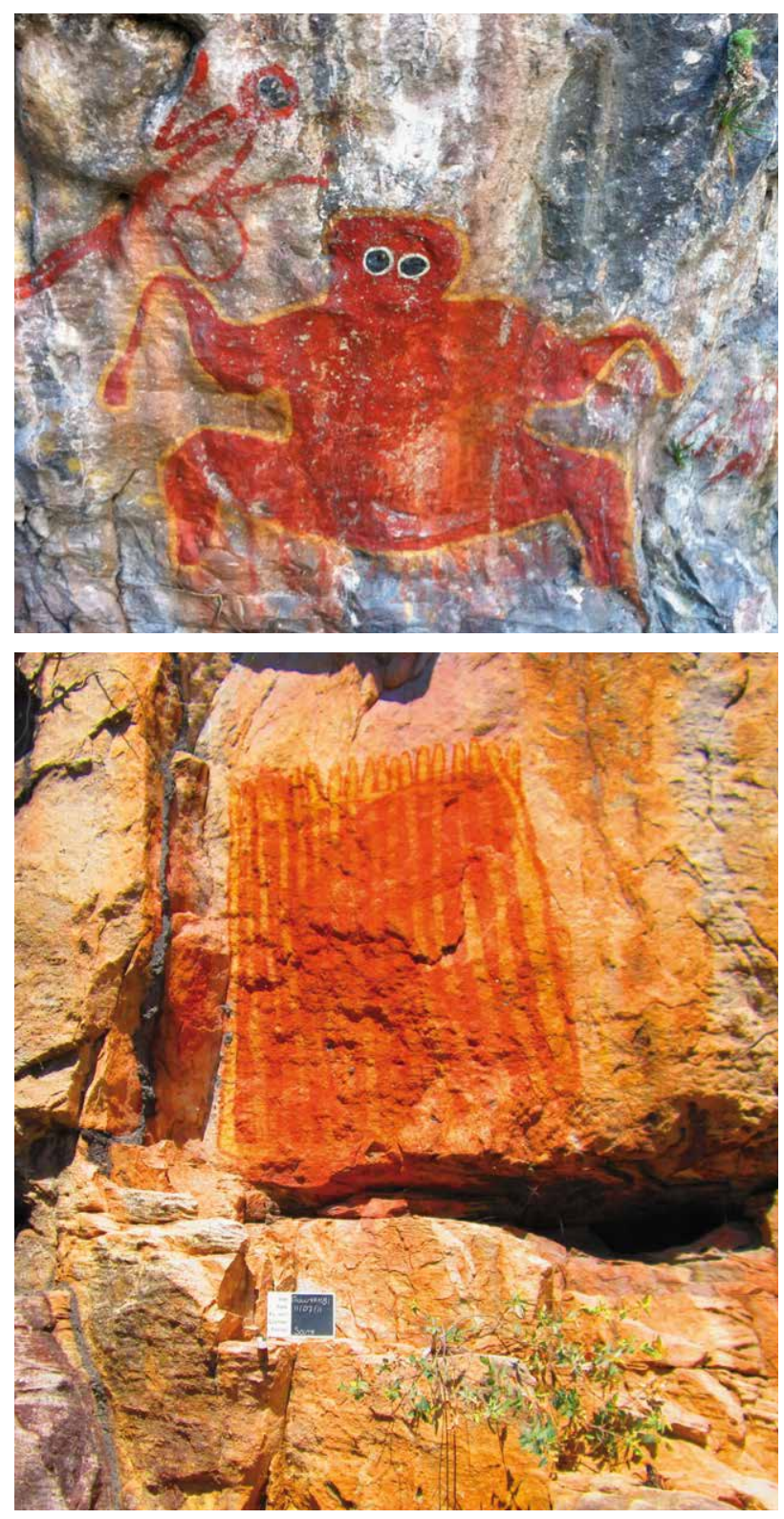

Figure 2 Depictions of Birriwilk and Njanjmah at Birriwilk rockshelter (above), and Njanjmah's raft at the Njanjmah art site (below; enhanced on the camera setting to saturate the colour) (photograph by Denis Shine July 2011).

overhang is deceptively deep, between 3 and $5 \mathrm{~m}$, but the site feels 'unroofed' owing to the ca $20 \mathrm{~m}$ height of the cliff face above. The site affords panoramic views to the south over Birriwilk lagoon, towards the Njanjmah rock art site, and west, towards the East Alligator River. During excavation (mid- to late dry season) the billabong is only ca $40 \mathrm{~m}$ south of the site, with the terrain falling sharply southward toward the lagoon (at a rate of ca $8 \mathrm{~m}$ per $20 \mathrm{~m}$ ).

In addition to the rock art, some surface ochre and occasional grinding hollows provide clear evidence for past usage. There was little evidence for disturbance, other than two minor 'hollows', potentially made by macropodoid marsupials or feral pigs (Sus scrofa); pig 'wallows' are common on the adjacent valley floor. The immediate vicinity of the site was covered with dense vegetation, with an upper canopy dominated by paperbarks (Melaleuca spp.) and eucalypts (mainly Eucalyptus miniata). These did not extend on to the floor of the rockshelter.

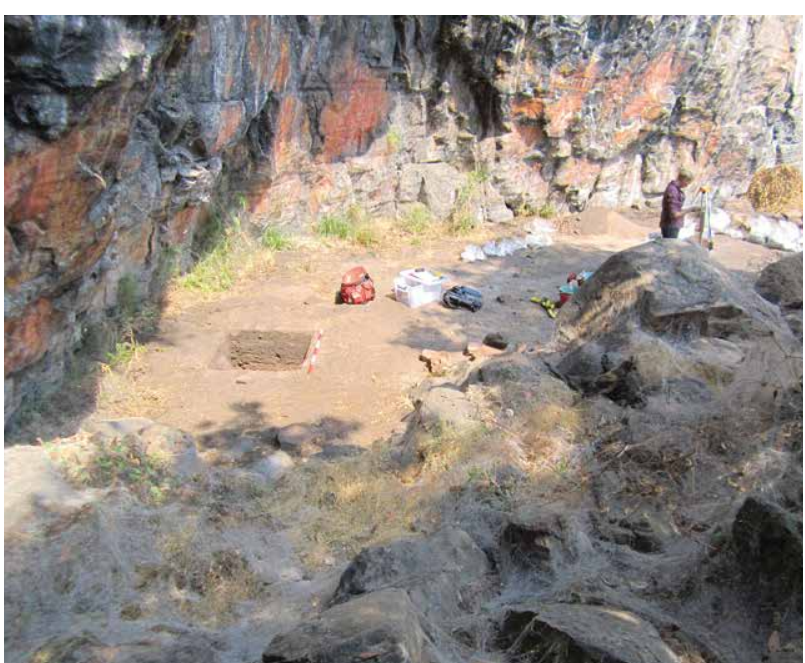

Figure 3 Birriwilk rockshelter, view to southeast (scale in $20 \mathrm{~cm}$ units photograph by Denis Shine July 2011).

\section{Previous Archaeological Investigations}

The rock art of the Birriwilk rockshelter was partially recorded by Gunn (1992) as part of a survey of sites of significance to Nakodjok. Gunn found that the rockshelter contained approximately 30 images, mainly consisting of bi or tri-chrome $\mathrm{x}$-ray fish including barramundi and catfish. A few animals in $\mathrm{x}$-ray and monochrome, and three adult hand stencils were also observed (Gunn 1992:15-18). While the most significant images to the Nayingguls are of Birriwilk and Njanjmah, Gunn (1992:15) considered two other images 'notable'. The first is a large, horizontal snake-like image in-filled with red and white rectangles; only the middle portion of this image remained by the time of the 2011 excavation. The second is a set of two parallel lines made of sprayed yellow dots, positioned in close proximity to the Birriwilk image.

While noting the uniqueness of the Birriwilk image, Gunn observed that a distinctive bold red and yellow design linked Birriwilk to the Njanjmah raft site and the Rainbow Serpent image at Ubirr, as well as potentially to other sites of mythological importance in Manilikarr Country. He suggested that both the Birriwilk image and the raft at Njanjmah had recently been repainted, judging by their good state of preservation relative to other images. Based on the subjects of the rock art, and superimposition observed at Njanjmah (where the raft is superimposed over a catfish), Gunn (1992:26) reasonably suggested that the rock art at both sites post-dates ca $1000 \mathrm{BP}$. Although the potential for archaeological excavation was noted, no excavations were undertaken at that time.

\section{The 2011 Excavations}

Archaeological investigations were conducted between 22 September and 5 October 2011, with a single $1 \mathrm{~m}$ square excavated at the base of the rock face adjacent to the panels of rock art in a seemingly undisturbed area (Figure 3). Excavation was completed in arbitrary excavation units (XUs) that followed observed strata. These averaged $2 \mathrm{~cm}$ in thickness within levels containing cultural deposits, and $4 \mathrm{~cm}$ in thickness through underlying colluvial deposits which contained a paucity of cultural material. Excavation ceased at $103 \mathrm{~cm}$ below surface (XU 38) due to impenetrable rock fall across the the excavation square. 


\begin{tabular}{|c|c|c|c|c|c|}
\hline Lab Code & $\mathbf{X U}$ & $\begin{array}{l}\text { Depth Below } \\
\text { Surface } \\
\text { (cm) }\end{array}$ & бC13 (\%o) & $\begin{array}{c}\text { Radiocarbon } \\
\text { Age (BP) }\end{array}$ & $\begin{array}{l}\text { Calibrated } \\
\text { Age (95.4\% } \\
\text { Probability) } \\
\text { (cal. BP) }\end{array}$ \\
\hline Wk-32918 & 8 & $14-16$ & $-27.1 \pm 0.2$ & $147 \pm 26$ & $\begin{array}{c}285-240(16.2 \%) \\
235-165(31.4 \%) \\
155-60(30.7 \%) \\
40(17 \%)\end{array}$ \\
\hline Wk-33542 & 12 & $21-24$ & $-26.0 \pm 0.2$ & $298 \pm 25$ & $\begin{array}{c}445-360(32.2 \%) \\
335-280(61.4 \%) \\
165-155(1.9 \%)\end{array}$ \\
\hline Wk-33540 & 15 & $28-30$ & $-26.0 \pm 0.2$ & $742 \pm 25$ & $\begin{array}{l}680-630(68.3 \%) \\
595-565(27.1 \%)\end{array}$ \\
\hline Wk-35588 & 19 & $37-39$ & $-24.7 \pm 0.2 \%$ & $3865 \pm 25$ & $\begin{array}{c}4382-4372(0.8 \%) \\
4352-4329(2.4 \%) \\
4298-4087(92.2 \%)\end{array}$ \\
\hline Wk-32919 & 24 & $48-50$ & $-25.3 \pm 0.2$ & $4056 \pm 31$ & $\begin{array}{c}4790-4760(7 \%) \\
4625-4425(88.4 \%)\end{array}$ \\
\hline Wk-33541 & 31 & $66-70$ & $-24.2 \pm 0.2$ & $4524 \pm 29$ & $5290-4970(95.4 \%)$ \\
\hline Wk-32917 & 38 & 93-103 & $-24.6 \pm 0.2$ & $4413 \pm 32$ & $\begin{array}{c}5270-5220(3.6 \%) \\
5215-5185(5.7 \%) \\
5120-5110(0.5 \%) \\
5065-4865(85.6 \%)\end{array}$ \\
\hline
\end{tabular}

Table 1 AMS radiocarbon dates on charcoal, calibrated using OxCAl 4.1 (Bronk Ramsey 2009) and the southern hemisphere calibration dataset (ShCal04) (McCormac et al. 2004).

All excavated sediment was dry sieved on site through $2.1 \mathrm{~mm}$ mesh. Sieved sediment was also collected and then processed at a dedicated facility in Kunbarlanja, where it was floated through $250 \mu \mathrm{m}$ mesh. Flotation was discontinued for XUs 24-38 owing to the scarcity of cultural material. The resultant flots and sieved material were transported to Monash University for sorting and analysis. All discarded sediment was returned to the site. Artefacts observed in situ (including some charcoal) were plotted in three dimensions and bagged individually where possible. In most cases, with the exception of XU 8, radiometric dating relied (by necessity) on charcoal recovered from the sieved fraction.

\section{Stratigraphy and Cultural Materials}

Six stratigraphic units (SUs) were observed in section (Figure 4), with sandy sediments (SUs 1-4, XUs 1-18) underlain by colluvial deposits of weathered sandstone and quartz (SU 6, XUs 24-38). These were separated by an intervening unit (SU 5, XUs 19-23), which is temporally related to SU 6, but presented as a mix of the overlying and underlying SUs.

Seven charcoal samples were radiocarbon dated, six from the sieved fraction (from XUs 12, 15, 19, 24, 31 and 38) and one collected in situ (from XU 8). Radiocarbon dates show good chronostratigraphic integrity, suggesting SUs 5 and 6 accumulated rapidly over a period of ca 500-1200 years ( $3865 \pm 25$ to $4413 \pm 32$ BP; Table 1 ).

Cultural materials included stone artefacts $(n=412)$, charcoal, bone, shell and worked $(n=23)$ and unworked ochre (not natural to the site). Glass was recovered from XUs 3-4, 6 and 8; the pieces in XUs 3-4 were flaked. A wooden spearhead was collected from XU 5. There was a rapid decline in the volume of cultural material with depth, which appears to reflect both increasing deterioration of organic materials with age and genuine patterns of site usage. The acidic soils of Birriwilk ( $\mathrm{pH}$ 3.1-4.1) are typical of archaeological sites in Arnhem Land
(Jones 1985) and have contributed to the decay of faunal (shell and bone) remains.

The distribution of cultural materials suggests initial use of the rockshelter from approximately $4524 \pm 29$ BP (XU 31). Evidence for this consists of an elevated charcoal frequency from XUs 29-32, small amounts of calcined bone and two fragments of worked ochre in XU 30. Intermittent usage continues from approximately $4056 \pm 31 \mathrm{BP}$ (XU 24), which is indicated by variable frequencies of cultural materials (primarily stone flakes and ochre).

The main period of site use was between $742 \pm 25 \mathrm{BP}$ (XU 15) and 50 years ago. Cultural materials (charcoal, faunal remains, stone artefacts and ochre) were concentrated between XUs 10-16, which date from ca 750 BP to between $298 \pm 25$ BP (XU 12) and $147 \pm 22 \mathrm{BP}(\mathrm{XU} 8)$. There is a clear decline in site use represented in the uppermost six XUs (Table 2). This paper focuses on stone artefacts and faunal remains, for which preliminary analyses are complete. The analysis of other assemblages, focused on archaeobotanical materials (primarily charcoal), is ongoing.

\section{Stone Artefacts}

Flaked stone artefacts were recovered in each of the uppermost 30 XUs, with the exception of XUs 1, 2, 23 and 29. These levels post-date $4524 \pm 29 \mathrm{BP}$. By far the highest concentration of stone artefacts was observed between XUs 10 and 16, which contained 297 lithic artefacts, $72 \%$ of the total by count. As stated, these XUs date from ca $750 \mathrm{BP}$ to the last few hundred years. The concentration of stone artefacts in these XUs is congruent with distributions of faunal materials and worked ochre (in total, XUs 13-17 contained $52 \%$ of the worked ochre by count: Table 2 ) and represents the primary period of site use.

Stone artefacts were also excavated in considerably reduced quantities, from the deposits immediately above and below XUs 10-16 (Table 2). XUs 5-7, post-dating $147 \pm 26 \mathrm{BP}$, contained 37 


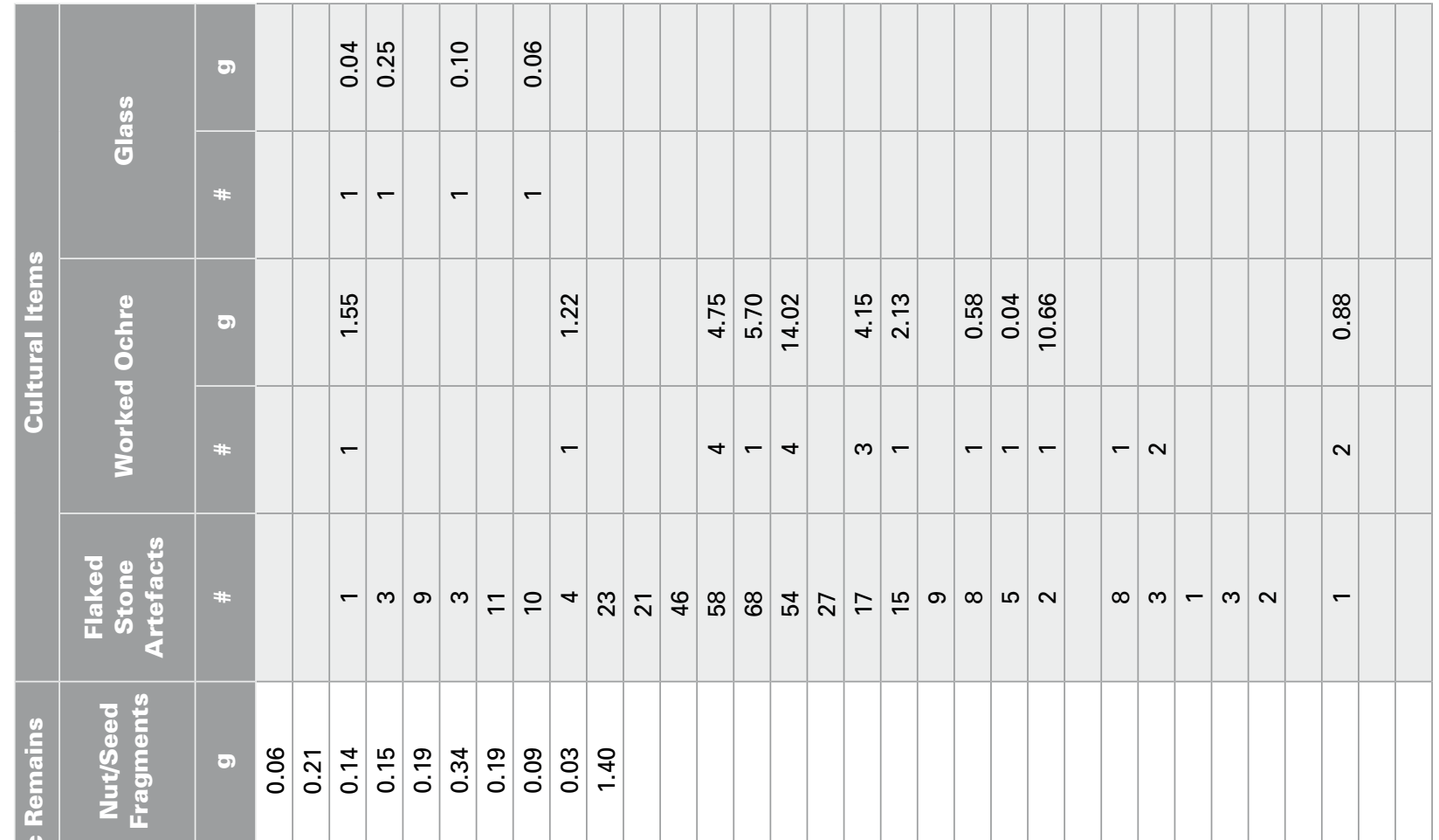

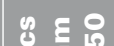

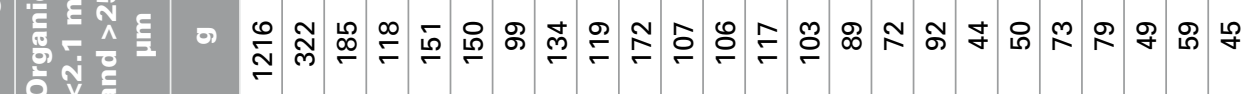

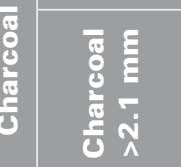

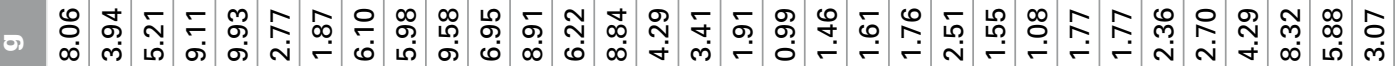

•)

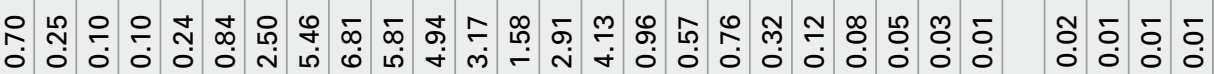

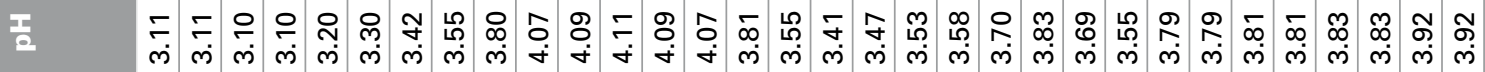

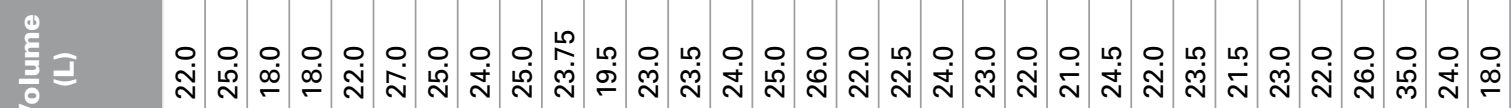

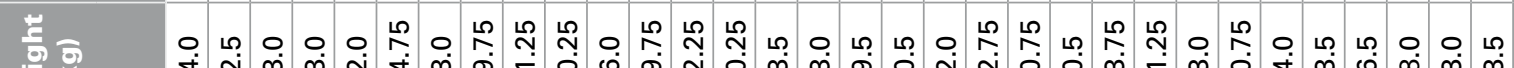
膤

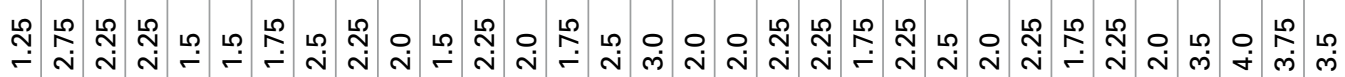

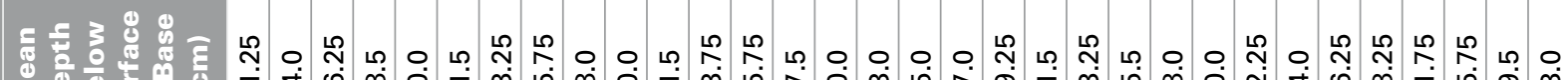

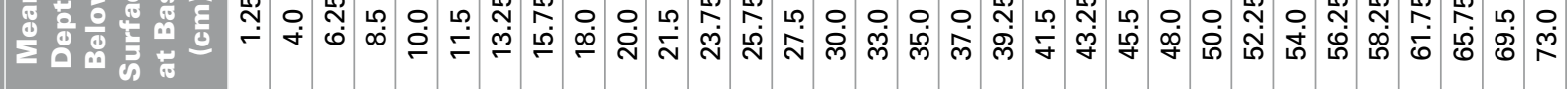

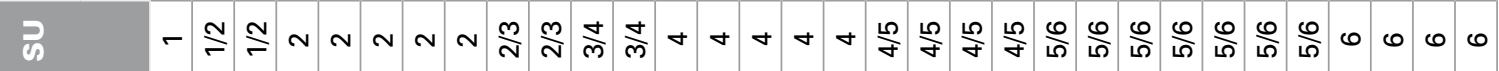

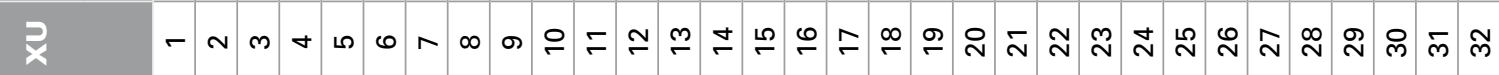




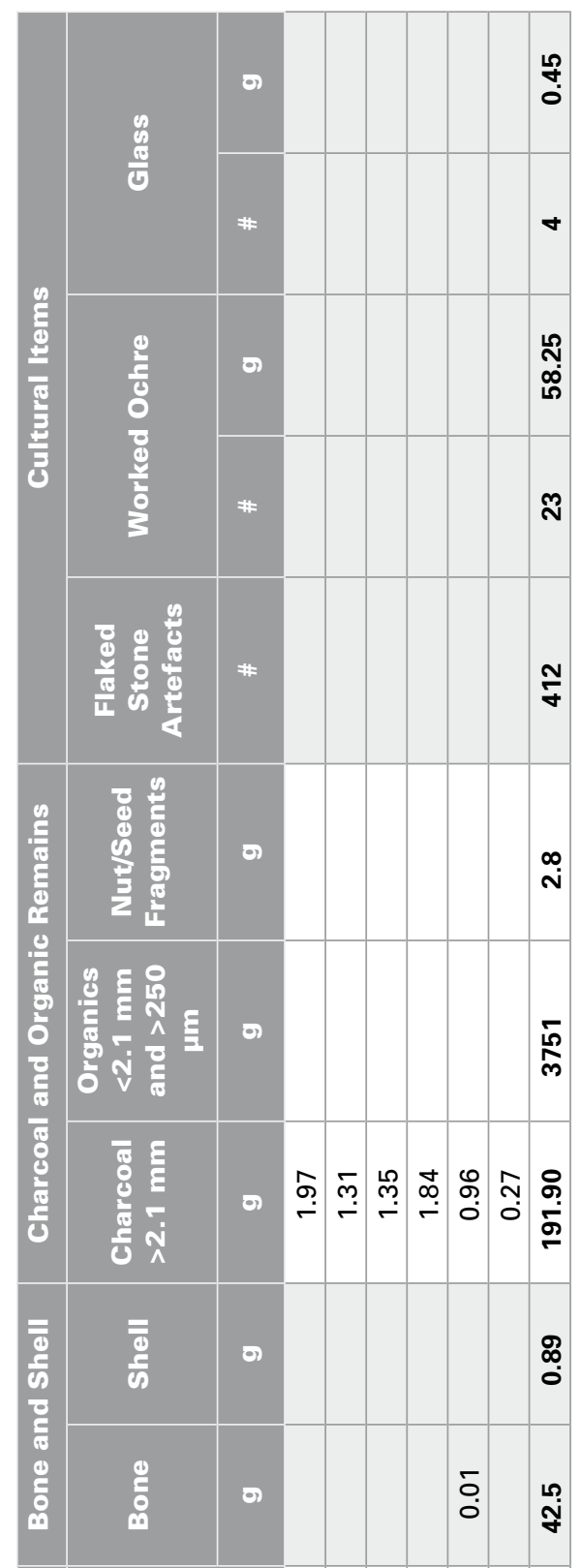

\begin{tabular}{|c|c|c|c|c|c|c|c|}
\hline 퐁 & $\begin{array}{l}\text { హे } \\
\text { ले }\end{array}$ & $\begin{array}{l}\text { ๙ે } \\
\text { ஸे }\end{array}$ & $\begin{array}{l}\text { के } \\
\text { ले }\end{array}$ & $\begin{array}{l}\text { న్ } \\
\text { ले }\end{array}$ & ๙઼ & 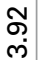 & \\
\hline$\frac{\stackrel{0}{E}}{3}=$ & $\begin{array}{l}\circ \\
\text { ¿े }\end{array}$ & $\stackrel{\circ}{\underset{\leftarrow}{\leftarrow}}$ & ì & $\begin{array}{l}0 \\
\stackrel{0}{-}\end{array}$ & $\begin{array}{l}0 \\
\dot{\theta}\end{array}$ & $\stackrel{\circ}{\circ}$ & 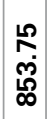 \\
\hline 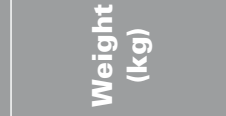 & $\begin{array}{l}\text { 이 } \\
\text { ָे }\end{array}$ & 올 & $\begin{array}{l}\circ \\
\stackrel{0}{\sim} \\
\stackrel{0}{0}\end{array}$ & $\begin{array}{l}\stackrel{n}{\sim} \\
\stackrel{\dot{m}}{2}\end{array}$ & 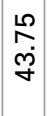 & $\stackrel{0}{=}$ & O̊ \\
\hline E & 임. & $\stackrel{\circ}{\dot{+}}$ & $\stackrel{O}{\dot{\forall}}$ & $\stackrel{0}{\dot{m}}$ & $\stackrel{\circ}{\dot{\gamma}}$ & $\begin{array}{l}\circ \\
\stackrel{0}{\circ}\end{array}$ & 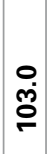 \\
\hline 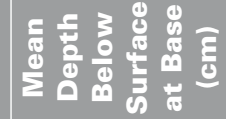 & $\begin{array}{l}\stackrel{\circ}{\circ} \\
\stackrel{\circ}{\sim}\end{array}$ & $\begin{array}{l}\stackrel{0}{\mathrm{~N}} \\
\infty\end{array}$ & $\begin{array}{l}0 \\
\dot{0} \\
\infty\end{array}$ & $\begin{array}{l}\circ \\
\infty \\
\infty\end{array}$ & ○्̀ & $\begin{array}{l}\text { ㅁ․ } \\
\text { ஜ் }\end{array}$ & \\
\hline ᄅ & 0 & 0 & 0 & 0 & 0 & 0 & $\bar{\sigma}$ \\
\hline 2 & m & ले & 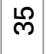 & $\stackrel{9}{m}$ & $\hat{m}$ & $\stackrel{m}{\infty}$ & \\
\hline
\end{tabular}

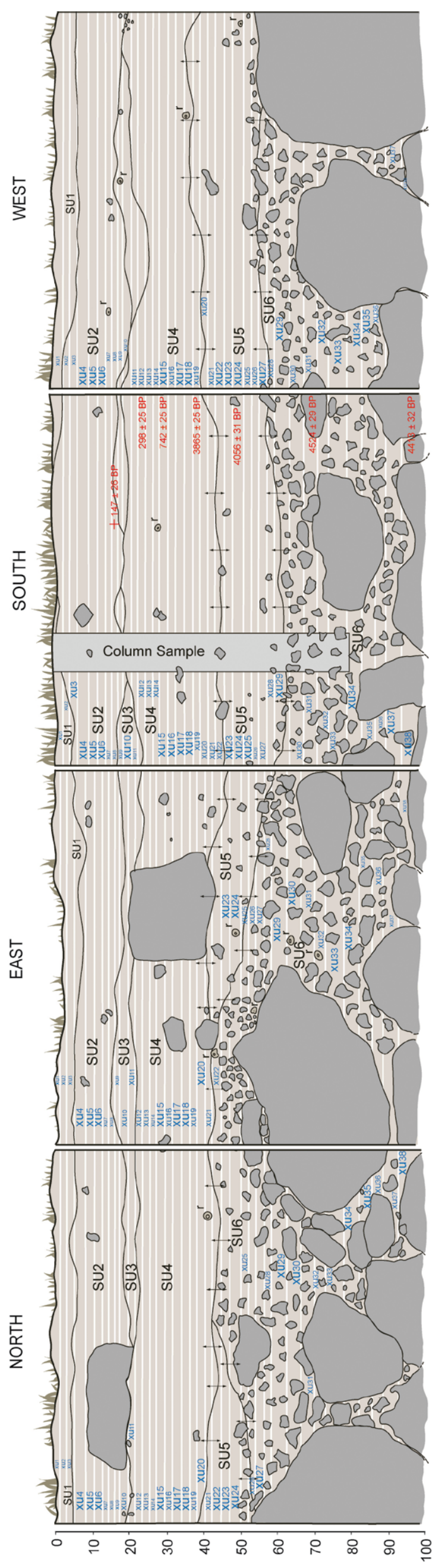

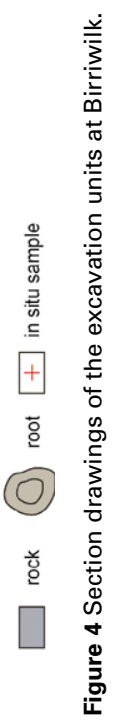


stone artefacts ( $9 \%$ of the total by count), indicating that use of the rockshelter continued in some capacity until the recent past. However, only four stone artefacts were recovered in levels above XU 5, indicating a virtual abandonment of the rockshelter, at least for occupation, at this point.

The density of stone artefacts also decreased markedly below XU 16. Relatively minor numbers of stone artefacts were contained within the colluviums. A total of 22 artefacts (5.3\% of the total count) were recovered from the upper colluviums, XUs 19-21, dated to approximately $3865 \pm 25$ BP (XU 19). Small quantities of stone artefacts $(n=17)$ were also collected at the interface between SUs 5 and 6 (XUs 24-28). A single artefact was collected from XU 30 in SU 6 (66 cm bs); no artefacts were recovered below this.

The artefact assemblage records a series of changes (Figure 5). Three raw materials were found throughout the sequence: an evenly-grained quartzite with good fracture properties, a high quality lustrous chert (generally red coloured) and a dark coloured tuff with rough texture but even fracture. The midHolocene levels contained a variety of materials, with tuff being the most common. From XU 21 until XU 16 the assemblages were dominated by chert. Post-750 BP, represented by XUs 3-15, quartzite was the dominant raw material. Given that all raw materials were procured during all time periods, we argue the shifts in dominant material are most likely a reflection of altered preferences and technological strategies. This interpretation aligns with the temporal correspondence of relatively high rates of quartzite artefact discard (XUs 15-10) and the discard of bifacial points (XUs 16-9), most of which were made on quartzite. We conclude that, during the last millennium, longstanding patterns of raw material procurement were altered to facilitate a technological emphasis on bifacial point manufacture. While the timing of this point production peak is somewhat later than has been reported elsewhere in the region (for example, at Nauwabila I where all but one of the quartzite points were recovered from levels post-dating $2970 \pm 80$ BP [ANU-3178; Jones 1985:194-195]), this only serves to further emphasise the localness of activity patterns and the geographic variation that is known to exist in western Arnhem Land lithic production (Hiscock 2009).

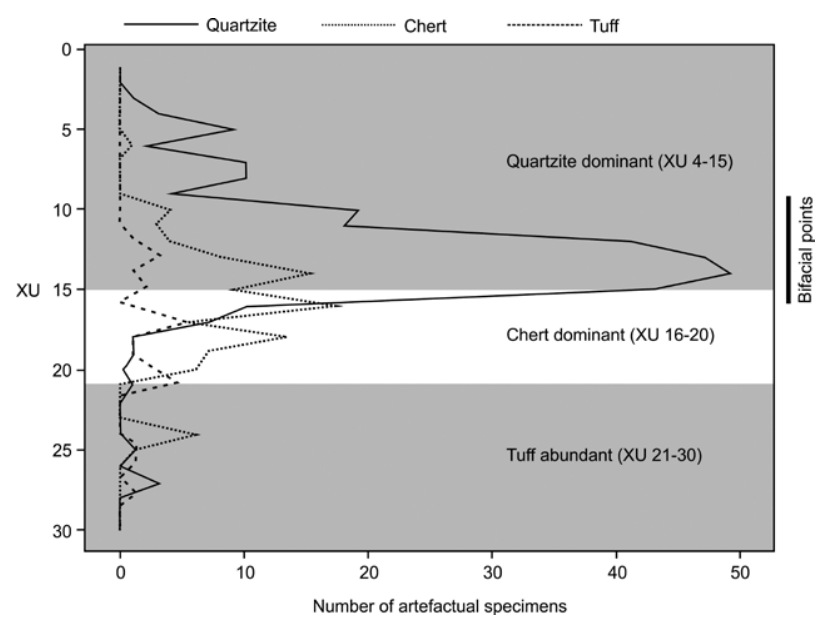

Figure 5 Lithic raw material changes through the Birriwilk sequence.

\section{Faunal Remains}

As commonly reported for sandstone rockshelter deposits in the region, the small quantities of recovered faunal remains showed clear signs of rapid organic degradation resulting from acidic soils (Table 2). The small quantities recovered are almost certainly not indicative of the original volume of material deposited in the site. Bone was present in all levels down to XU 25 and in very small quantities in SU 6 in XUs 27-31 and 37. All of the bone preserved below XU 15 was calcined, indicative of prolonged burning at very high temperatures $\left(>800^{\circ} \mathrm{C}\right.$; Brain 1993), which is normally seen as a product of cultural activity (for a discussion see Aplin et al. 2010; Nicholson 1993). However, the absence of unburnt bone from lower excavation units is not solely related to poor preservation, as the vertical distribution of the bone and the stone artefacts align, indicating that the primary activity at the site post-dates ca $750 \mathrm{BP}$.

The vertical distribution of bone was highest from XUs 9-16 with two peaks, one in XUs 10-13 and another in XU 16 (Figure 6). In combination, XUs $9-16$ contained $81 \%$ of the bone. Unburnt bone, an indicator of less complete organic destruction, was restricted to XUs 6-13 (Figure 7). The near-absence of bone from the uppermost six XUs (Table 2) aligned with the vertical distribution of stone artefacts (Figure 5), and results from reduced activity, or abandonment of occupation at the site. This is also indicated by a decline in burning activity (Table 2), after an observed peak in XUs 8-9 dating to $147 \pm 22 \mathrm{BP}$.

Three classes of vertebrates are represented in the bone assemblage (Figure 8). Turtles (Family Chelidae) were represented throughout the profile by small fragments of carapace and plastron, including in XUs 24 and 27. These might be derived from any of the four chelid species (long-necked Macrochelodina burrungandjii, short-necked Myuchelys latisternum, Emydura tanybaraga and Elseya dentate) which occur in the creeks and billabongs along the escarpment. No material could be referred to the soft-shelled turtle (Carettochelys insculpta), which also occurs in the region.

Fish bone was present in almost every XU and typically makes up $30 \%$ or more of each sample by weight, though its fragmentary nature hindered taxonomic identification. Nevertheless, it includes material that is referable to one or more species of fork-tailed catfish (Family Ariidae). This group of floodplain and lowland river species has a highly distinctive

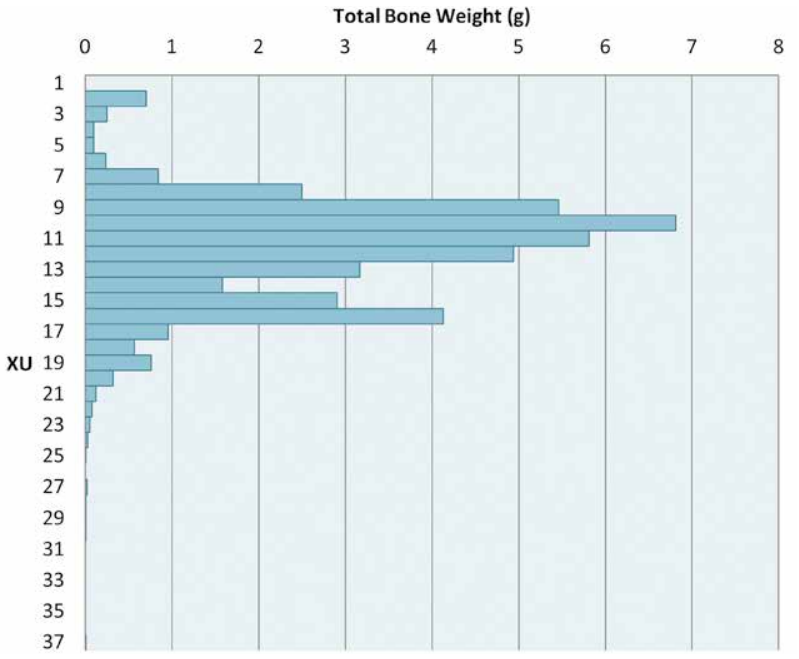

Figure 6 Stratigraphic distribution of excavated bone by weight $(\mathrm{g})$. 


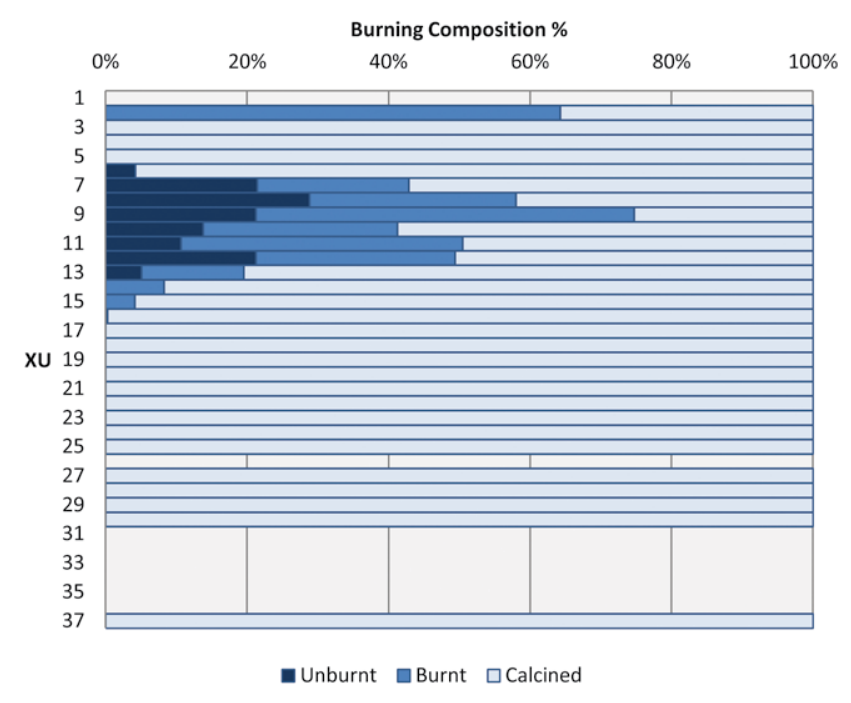

Figure 7 Stratigraphic distribution of three burning classes of bone as a percentage of total bone weight, showing the effects of differential rates of post-depositional breakdown on unburnt, incompletely burnt and calcined bone.

surface texture to the dorsal cranial bones, robust and distinctive dentigerous bones, as well as a uniquely lenticular otolith (Acero and Bentacur 2007), all of which make it conspicuous when present. Several dentigerous fragments compare well with examples of Polymenidae and may represent the threadfin salmon (Polydactylus sheridani) which frequents the deeper tidal creeks in the region. Several other families of fish taxa are represented but presently remain unidentified. A total of 58 species of fish have been recorded in the East Alligator River catchment, the largest tally for any river system in tropical Australia (Burrows 2008). Of these, 15 or more attain adult lengths of $30 \mathrm{~cm}$ or more, making them likely targets for focused pursuit.

Bone that is recognisably mammalian makes up only a small percentage of the total collection. However, more fragmented mammal bone probably makes up a significant proportion of the taxonomically unallocated remains. All diagnostic mammal remains belong to macropodoid marsupials: an edentulous maxilla of Bettongia sp. in XU 6, fragmentary molars and incisors of a large Macropus species in XUs 9, 12 and 13, and several partial molars of a wallaby in XU 15 , consistent in size with a species of rock (Petrogale sp.) or hare wallaby (Lagorchestes sp.). The unidentified bone includes many small pieces of long bone shafts, but few if any are sufficiently thin-walled to be referable to a species of flying fox (Pteropus sp.).

Two unidentified long bone shaft fragments from XU8 show parallel transverse cut marks. No other evidence for manufacture or use of bone artefacts was observed.

The most relevant comparative data for the Birriwilk bone assemblage derives from two collections made from loose surface contexts in Anbangbang I and Djuwarr I, which also contained significant numbers of fish and turtle (Foley 1985). However, these exceptionally well preserved assemblages differed to Birriwilk in the presence of a wider variety of reptiles (especially Agamidae and Varanidae) and the abundance of bandicoots and flying foxes. All of these taxa are usually still recognisable in highly degraded assemblages, typically from fragmentary teeth and foot bones in the case of bandicoots, fragments of dentaries and teeth in the case of flying foxes, and fragmentary dentaries

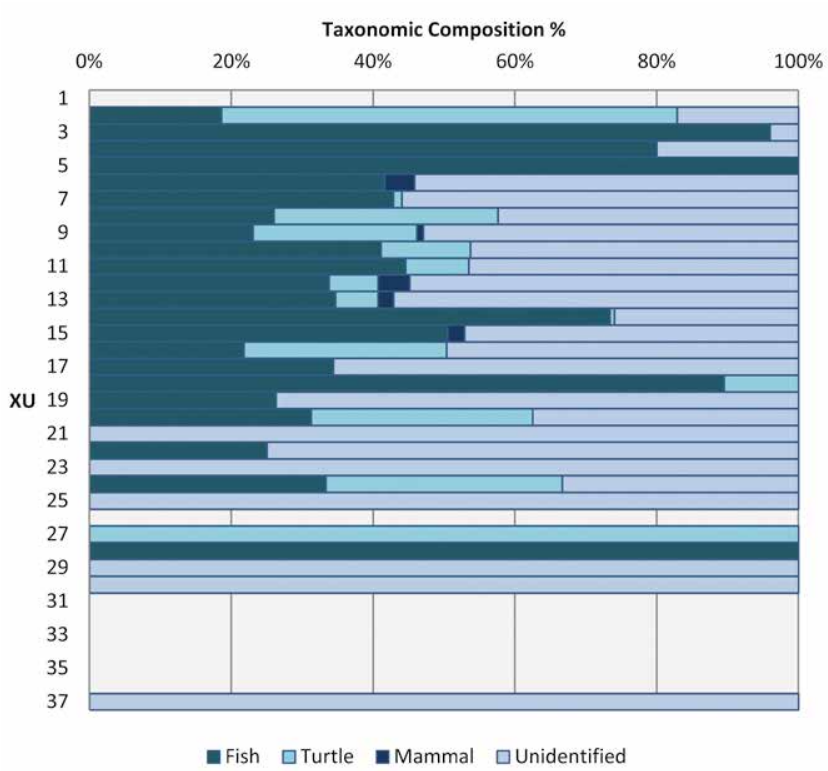

Figure 8 Variation in the high level taxonomic composition of the assemblage through the stratigraphic profile.

and vertebrae in the case of reptiles. The contrast between the assemblages is thus unlikely to be due to differential preservation, with the Birriwilk assemblage, indicating a greater focus on the faunal resources of the wetland system in which it is located, and less emphasis on more general foraging away from the wetlands, including in surrounding upland regions.

\section{Conclusions}

Excavations at Birriwilk indicate two principal phases of human settlement: ephemeral visitation from $4500 \mathrm{BP}$ and sustained settlement 750-50 BP. The earliest phase included minor deposition of stone artefacts, worked ochre, calcined bone and evidence of increased burning. Considered in terms of the overall distribution of cultural materials (and burning evidence), the mid-Holocene activity was minor and the main period of site use did not commence until the last millennium.

The main occupation of Birriwilk dates from ca 750 to $50 \mathrm{BP}$. The stone artefacts and faunal remains suggest site usage was most intensive from $750 \mathrm{BP}$ to approximately 250-200 BP. Analysis of the faunal materials from this period indicates that hunting and foraging was focused on adjacent wetland habitats. This activity distinguishes Birriwilk from other previously investigated sites, and suggests a greater emphasis was placed by the occupants of Birriwilk on freshwater resources. The connection of the freshwater environment with the site continues to be recorded in the Birriwilk mythologies, which remain significant today; the adjacent lagoon is also regarded as a djang site. Occupation from $750 \mathrm{BP}$ was accompanied by an adoption of quartzite as the preferred raw material and an emphasis on the manufacture of bifacial quartzite points. Although worked ochre fragments were dispersed throughout the deposit, more than half were also recovered from these levels, suggesting that much of the rock art dates to between ca 750 and 200 BP. This age is consistent with previously conjectured ages for the rock art at the site based on the prominence of freshwater species (Gunn 1992). 
The use of the rockshelter for subsistence related activities appears to have declined post-250-200 BP. However, between 250-150 BP, limited amounts of stone artefacts and faunal remains and large quantities of charcoal (suggesting extensive burning) continued to accumulate. A further decrease in cultural materials occurred in the recent past (XUs 5-6), although use of the site is still indicated by worked ochre and 'European' finds from the uppermost excavation levels (Table 2). Although archaeological evidence indicates that recent occupation was much less sustained than in the preceding period, Nakodjok recollected rock art events and camping at the rockshelter. The decrease in occupation at Birriwilk potentially resulted from changing settlement patterns linked to the foundation of Kunbarlanja cattle station in 1909-10, followed by the development of the Kunbarlanja Anglican mission and town. Alternatively, reduced activity at Birriwilk may reflect a shift in site usage to a purely ritual focus, as opposed to camping while hunting and foraging.

The excavation results at Birriwilk are consistent with many floodplain sites in the region (e.g. Brockwell 1989; Hiscock 1999; Jones 1985). These sites are thought to have expanded across the floodplains as the freshwater environment stabilised in the last 1500 years (e.g. Allen 1987, 1989; Allen and Barton 1989; Brockwell 2011; Jones 1985). The archaeological evidence, rock art and oral traditions from Birriwilk all link the site to the adjacent freshwater lagoon and indicate that the primary period of occupation was short-lived, over a period of 500 to 700 years. This raises the intriguing possibility that the Birriwilk story may have developed in this period as people reinterpreted their changed freshwater landscape. The settlement history (as outlined here) will be further examined in future publications to assess the antiquity of the Birriwilk story and help clarify the changing character of people's connections to the landscapes of western Arnhem Land during the later Holocene.

\section{Acknowledgements}

Most importantly we thank Nakodjok for inviting us to undertake archaeological excavations and for his support during fieldwork. We acknowledge members of the Nayinggul family for assisting and caring for us during fieldwork, particularly Lawrence and Lionel Jr, who worked on the excavations, and Alfred and Andronicus, who narrated oral traditions and facilitated survey. We also thank the community of Kunbarlanja for their support, as well as Injalak Arts and KNP who provided accommodation and logistical support. Thanks also to Sally May (ANU) who introduced us to both the Nayingguls and the wider community. The template used for Figure 4 in this text was kindly provided by Bruno David and Ian McNiven. Finally, we thank the volunteers during both excavation and post-excavation: Sean-Paul Stephens and Elissa Teperman. This field research was funded by a Monash Research Accelerator grant awarded to TD and ongoing analyses are partially funded by an Australian and Pacific Science Foundation grant awarded to TD and DS. Radiometric dating and archaeological sorting were provided by TD and funded by the Student Summer Scholarship Scheme at Monash University. The $\mathrm{PhD}$ research of DS is supported by a Monash International Postgraduate Research Award Scholarship.

\section{References}

Aboriginal Arts Board 1979 Oenpelli Bark Painting. Sydney: Ure Smith.

Acero, A.P. and R. Betancur 2007 Monophyly, affinities and subfamilial clades of sea catfishes (Siluriformes: Ariidae). Ichthyological Exploration of Freshwaters 18(2):133-143.

Allen, H. 1987 Holocene mangroves and middens in northern Australia and Southeast Asia. Bulletin of the Indo-Pacific Prehistory Association 7:1-16.

Allen, H. 1989 Late Pleistocene and Holocene settlement patterns and environment, Kakadu, Northern Territory, Australia. Bulletin of the Indo-Pacific Prehistory Association 9:92-117.

Allen, H. and G. Barton 1989 Ngarradj Warde Djobkeng: White Cockatoo Dreaming and the Prehistory of Kakadu. Sydney: University of Sydney.

Aplin, K., F. Ford and P. Hiscock 2010 Early Holocene human occupation and environment of the southeast Australian Alps: New evidence from the Yarrangobilly Plateau, New South Wales. In S.G. Haberle, J. Stevenson and M. Prebble (eds), Altered Ecologies: Fire, Climate and Human Influence on Terrestrial Landscapes, pp.187-212. Terra Australis 32. Canberra: ANU E Press.

Berndt, C.H. 1962 The arts of life. Westerly 1(2):82-91.

Berndt, C.H. and R.M. Berndt 1989 The Speaking Land: Myth and Story in Aboriginal Australia. Melbourne: Penguin Books.

Birch, B. 2006 A First Dictionary of Erre, Mengerrdji and Urningangk: Three Languages from the Alligator Rivers Region of North Western Arnhem Land, Northern Territory, Australia. Jabiru: Gundjeihmi Aboriginal Corporation.

Brain, C.K. 1993 The occurrence of burnt bones at Swartkrans and their implications for the control of fire by early hominids. In C.K. Brain (ed.), A Cave's Chronicle of Early Man,pp.229-242. Transvaal: Transvaal Museum.

Brandl,E. 1968 Aboriginal rock designs in beeswax and description of cave painting sites in western Arnhem Land. Archaeology and Physical Anthroopology in Oceania 3:19-29.

Brockwell, C., P. Bourke, A. Clarke, C.Crassweller, P. Faulkner, B. Meehan, S. O'Connor, R. Sim and D. Wesley 2011 Holocene settlement of the northern coastal plains, Northern Territory, Australia. Beagle: Records of the Museums and Art Galleries of the Northern Territory 27:1-22.

Brockwell, C.J. 1989 Archaeological Investigations of the Kakadu Wetlands, Northern Australia. Unpublished MA thesis, School of Anthropology and Archaeology, The Australian National University, Canberra.

Bronk Ramsey, C. 2008 Radiocarbon dating: Revolutions in understanding. Archaeometry 50(2):249-275.

Burrows, D. 2008 Freshwater fish. In G.P. Lukacs and C.M. Finlayson (eds), A Compendium of Ecological Information on Australia's Northern Tropical Rivers. Sub-Project 1 of Australia's Tropical Rivers - An Integrated Data Assessment and Analysis (DET18), pp.1-20. Townsville: Land and Water Australia, National Centre for Tropical Wetland Research.

Chaloupka, G., N. Kapirigi, B. Nayidji and G. Namingum 1985 Cultural Surveys of Balawurru, Deaf Adder Creek, Amarrkananga, Canon Hill and the Northern Corridor. Unpublished report prepared for the Australian National Parks and Wildlife Service.

Edwards, R. 1979 Australian Aboriginal Art: The Art of the Alligator Rivers Region, Northern Territory. Canberra: Australian Institute of Aboriginal Studies.

Foley, D. 1985 Faunal analysis of Anbangbang 1 and Djuwarr 1. In R. Jones (ed.), Archaeological Research in Kakadu National Park, pp.97-102. Special Publication 13. Canberra: Australian National Parks and Wildlife Service.

Gunn, R.G. 1992 Mikinj: Rock Art, Myth and Place (Sites of Significance to Jacob Nayinggul). Unpublished report prepared for the Australian Institute of Aboriginal and Torres Strait Islander Studies.

Hiscock, P. 1999 Holocene coastal occupation of western Arnhem Land. In J. Hall and I. McNiven (eds), Australian Coastal Archaeology, pp.91-103. Research Papers in Archaeology and Natural History 31. Canberra: ANH Publications, Department of Archaeology and Natural History, Research School of Pacific 
and Asian Studies, The Australian National University.

Hiscock, P. 2009 Reduction, recycling and raw material procurement in western Arnhem Land. In B. Adams and B.S. Blades (eds), Lithic Materials and Paleolithic Societies, pp.78-94. Oxford: Wiley-Blackwell

Jelínek, J. 1976 The social meaning of north Australian rock paintings. Anthropologie 14(1):83-87.

Jelínek, J. 1978 Obiri: A rock art gallery in Arnhem Land, north Australia. Anthropologie 16:35-65.

Jelínek, J. 1979 Skeletal remains from Arnhem Land. Anthropologie 17(2/3):159174.

Jones, R.M. 1985 Archaeological Research in Kakadu National Park. Special Publication 13. Canberra: Australian National Parks and Wildlife Service.

Kamminga, J. and H. Allen 1973 Alligator Rivers Environmental Fact Finding Study. Auckland: Department of Anthropology.

McCormac, F.G., A.G. Hogg, P.G. Blackwell, C.E. Buck, T.F.G. Higham and P.J. Reimer 2004 SHCal04 Southern Hemisphere Calibration, 0-11.0 cal kyr BP. Radiocarbon 46(3):1087-1092.

Merlan, F. 1998 Caging the Rainbow: Places, Politics and Aborigines in a North Australian Town. Honolulu: University of Hawai' i Press.

Mountford, C.P. (ed.) 1956 Records of the American-Australian Expedition to Arnhem Land 1948: Art, Myth and Symbolism. Melbourne: Melbourne University Press.
Nicholson, R.A. 1993 A morphological investigation of burnt animal bone and an evaluation of its utility in archaeology. Journal of Archaeological Science 20:411-428.

Schrire, C. 1982 The Alligator Rivers: Prehistory and Ecology in Western Arnhem Land. Terra Australis 7. Canberra: Department of Prehistory, Research School of Pacific Studies, The Australian National University.

Taçon, P.S.C. 1989 From Rainbow Snakes to 'X-Ray' Fish: The Nature of the Recent Painting Tradition in Western Arnhem Land. Unpublished PhD thesis, School of Archaeology and Anthropology, The Australia National University, Canberra.

Taçon, P.S.C., M. Wilson and C. Chippendale 1996 Birth of the Rainbow Serpent in Arnhem Land rock art and oral history. Archaeology in Oceania 31(3):103-124.

White, C. 1967a Plateau and Plain: Prehistoric Investigations in Arnhem Land, Northern Territory. Unpublished PhD thesis, Department of Anthropology and Sociology, Research School of Pacific Studies, The Australian National University, Canberra.

White, C. 1967b The prehistory of the Kakadu people. Mankind 6(9):426-431.

White, C. 1971 Man and environment in northwest Arnhem Land. In D.J. Mulvaney and J.Golson (eds), Aboriginal Man and Environment in Australia, pp.141-157. Canberra: Australian National University Press.

White, C. and N. Peterson 1969 Ethnographic interpretations of the prehistory of western Arnhem Land. Southwestern Journal of Anthropology 25(1):45-67. 